\title{
Low birth weight and longitudinal trends of cardiovascular risk factor variables from childhood to adolescence: the bogalusa heart study
}

\author{
Maria G Frontini ${ }^{1}$, Sathanur R Srinivasan ${ }^{2}$, Jihua $\mathrm{Xu}^{2}$ and \\ Gerald S Berenson*2
}

Address: ${ }^{1}$ Department of Public Health, Eastern Virginia Medical School, PO Box 1980, Norfolk VA 23507-1980, USA and ${ }^{2}$ Tulane Center for Cardiovascular Health and Department of Epidemiology, Tulane University Health Sciences Center, New Orleans, LA, USA

Email: Maria G Frontini - frontini@tulane.edu; Sathanur R Srinivasan - ssriniv1@tulane.edu; Jihua Xu - jxu@tulane.edu; Gerald S Berenson* - berenson@tulane.edu

* Corresponding author

Published: 03 November 2004

BMC Pediatrics 2004, 4:22 doi:10.1 |86/147|-243|-4-22
Received: 27 May 2004

Accepted: 03 November 2004

This article is available from: http://www.biomedcentral.com//47/-243 I/4/22

(C) 2004 Frontini et al; licensee BioMed Central Ltd.

This is an Open Access article distributed under the terms of the Creative Commons Attribution License (http://creativecommons.org/licenses/by/2.0), which permits unrestricted use, distribution, and reproduction in any medium, provided the original work is properly cited.

\begin{abstract}
Background: Several studies have linked low birth weight to adverse levels of cardiovascular risk factors and related diseases. However, information is sparse at a community level in the U.S. general population regarding the effects of low birth weight on the longitudinal trends in cardiovascular risk factor variables measured concurrently from childhood to adolescence.

Methods: Longitudinal analysis was performed retrospectively on data collected from the Bogalusa Heart Study cohort ( $\mathrm{n}=1141$; $57 \%$ white, $43 \%$ black) followed from childhood to adolescence by repeated surveys between 1973 and 1996. Subjects were categorized into low birth weight (below the race-specific $10^{\text {th }}$ percentile; $n=123$ ) and control (between race-specific $50-75^{\text {th }}$ percentile; $n=296$ ) groups.

Results: Low birth weight group vs control group had lower mean HDL cholesterol $(p=0.05)$ and higher LDL cholesterol ( $p=0.05$ ) during childhood (ages $4-1$ I years); higher glucose $(p=0.02)$ during adolescence. Yearly rates of change from childhood to adolescence in systolic blood pressure $(p=0.02)$, LDL cholesterol $(p=0.05)$, and glucose $(p=0.07)$ were faster, and body mass index $(p=0.03)$ slower among the low birth weight group. In a multivariate analysis, low birth weight was related independently and adversely to longitudinal trends in systolic blood pressure ( $P$ $=0.004)$, triglycerides $(p=0.03)$, and glucose $(p=0.07)$, regardless of race or gender. These adverse associations became amplified with age.

Conclusions: Low birth weight is characterized by adverse developmental trends in metabolic and hemodynamic variables during childhood and adolescence; and thus, it may be an early risk factor in this regard.
\end{abstract}

\section{Background}

The growth of a fetus in an undernourished intrauterine environment is considered to result in adaptive fetal programming or metabolic imprinting with 
pathophysiologic consequences later in life [1-4]. It is contended that low birth weight at term $(<2500 \mathrm{~g})$, a surrogate for impaired gestational environment, is uncommon in industrialized societies, and deprivations that existed before the second world war no longer apply to pregnancies at present $[5,6]$. In reality, the United States birth data for year 2002 show a prevalence of $7.8 \%$ low birth weight, with blacks showing almost twice the rate of whites [7]. Studies world-wide, regardless of socio-economic background, have linked low birth weight to increased risk of insulin resistance, dyslipidemia, hypertension, coronary heart disease, and type 2 diabetes [8$13]$, although some studies have found a weak or no associations in this regard [5,14-16].

Several studies including our own have examined the association between low birth weight and selected cardiovascular risk factor variables in childhood and adolescence [17-27]. However, information is scant on data linking low birth weight to longitudinal changes of cardiovascular risk factor variables measured simultaneously and serially from childhood to adolescence. As part of the Bogalusa Heart Study, a biracial (black-white) community-based investigation of evolution of cardiovascular risk since childhood [28], the present analysis examines the relationship between low birth weight and the longitudinal trends of adiposity, blood pressure, lipids and lipoproteins, and measures of glucose homeostasis from childhood to adolescence.

\section{Methods}

\section{Study cohorts}

Between 1973 and 1996, 7 cross-sectional surveys of children and adolescents were conducted in the community (65\% white, 35\% black) of Bogalusa, LA. This panel design, based on repeated cross-sectional examinations performed every 3 to 4 years, resulted in serial observations required for the longitudinal analysis. For the present report, two sets of data were merged as described previously [21]: 1) singleton new born cohort participants $(\mathrm{n}=233)$ whose weights were measured at birth as part of the initial examination during 1973-1974; and 2) singletons $(\mathrm{n}=1213)$ aged $7-11$ years who participated in 1987-1988 cross-sectional survey and whose birth weight records were obtained from the Office of Vital Statistics in New Orleans in 1991. Of those with birth weight data (n $=1436), 1329$ subjects participated in 2 to 7 surveys of children and adolescents. Exclusion of those with missing data $(n=170)$, congenital heart disease $(n=11)$, and diabetes $(n=7)$ resulted in 1141 eligible subjects $(57 \%$ white, $47 \%$ female).

Low birth weight and control groups were selected from the eligible cohort, according to birth weight percentile cut points [29]. Subjects $(n=123)$ who had birth weight below the race-specific $10^{\text {th }}$ percentile (whites: $<2749$ g; blacks: $<2438$ g) were categorized as low birth weight group; those $(\mathrm{n}=296)$ in the upper normal range of 50$75^{\text {th }}$ percentile (whites: $3402-3770 \mathrm{~g}$; blacks: $3133 \mathrm{~g}-$ $3487 \mathrm{~g}$ ) as control group. Birth weights above the $75^{\text {th }}$ percentile were not included in the control group because of the u-shaped associations between birth weight and risk factors or disease $[3,30]$. Race-specific percentile, rather than World Health Organization (WHO) criterion for low birth weight $(<2500 \mathrm{~g})$ was used to define low birth weight because of black-white differences in birth weight distribution $[31,32]$.

\section{General examination}

Identical protocols were used by trained examiners across all surveys [33]. Subjects were instructed to fast for 12 hours prior to screening, and compliance was determined by interview on the morning of examination. Anthropometric and blood pressure measurements were made in replicate and mean values were used.

Height and weight were measured 2 times; subscapular skinfold thickness 3 times. Body mass index (BMI) calculated as weight in $\mathrm{kg}$ divided by the square of the height in meters was used as a measure of overall adiposity; subscapular skinfold for truncal fatness. The reproducibility in terms of intraclass (intra-observer) correlation coefficient was greater than 0.99 for weight and height, and greater than 0.97 for subscapular skinfold.

Blood pressure levels were measured in 6 replicates by 2 randomly assigned nurses on the right arm of subjects in a relaxed, sitting position. Systolic and diastolic blood pressures were recorded at the first, fourth, and fifth Korotkoff phases using mercury sphygmomanometer. For this analysis fourth phase was used for diastolic blood pressure because in our experience the fourth phase is more reliably measured in children and more predictive of adult hypertension [34].

\section{Laboratory analyses}

From 1973 to 1986 cholesterol and triglyceride levels in serum were measured using chemical procedures on Technicon Autoanalyzer II (Technician Instrument Corp., Tarrytown, NY). Since then these measurements were done using enzymatic procedures on Abbott VP instrument (Abbott laboratories, North Chicago, IL). Serum lipoprotein cholesterols were analyzed by a combination of heparin-calcium precipitation and agar-agarose gel electrophoresis procedures [35]. Both chemical and enzymatic procedures met the performance requirement of the Lipid Standardization Program of the Centers for Disease Control and Prevention, Atlanta, GA. The laboratory has been monitored for precision and accuracy by the agency's surveillance program since 1973. For example, the average 
bias in levels of total cholesterol on CDC control samples ranged from -0.1 to $-1.6 \mathrm{mg} / \mathrm{dL}$ between different crosssectional surveys, with no consistent pattern over time within or between surveys. The intraclass correlation coefficients between the blind duplicate (10\% random sample) values ranged from 0.87 to 0.99 for total cholesterol; 0.88 to 0.99 for triglycerides; 0.86 to 0.98 for LDL cholesterol; and 0.86 to 0.98 for HDL cholesterol.

Plasma immunoreactive insulin levels were measured by a commercial radioimmunoassay kit (Phadebas, Pharmacia Diagnostics, Piscataway, NJ). Plasma glucose was measured by a glucose oxidase method either using a Beckman glucose analyzer (Beckman Instruments, Fullerton, CA) or as part of a multichemistry (SMA20) profile. The intraclass correlation coefficient between blind duplicate values ranged from 0.94 to 0.98 for insulin and 0.86 to 0.98 for glucose. An index of insulin resistance was calculated according to the homeostasis assessment model formula [36]: HOMA-IR=fasting insulin $(\mu \mathrm{u} / \mathrm{mL}) \times$ fasting glucose $(\mathrm{mmol} / \mathrm{L}) \div 22.5$.

\section{Statistical analyses}

For test of significance glucose and insulin were logarithmically transformed to approach normality. The average of multiple measurements for subjects within age groups 4 to 11 and 12 to 18 years corresponding to childhood and adolescence periods was used to calculate mean levels of risk variables by birth weight status and age groups. Mean levels of risk variables within each age group were compared between low birth weight and control group by a general linear model, adjusting for age, race, and gender. The longitudinal rates of change in risk variables was assessed by the generalized estimation equation (GEE) method [37] with age as predictor, adjusting for race and gender. Independent association of low birth weight with longitudinal trends of risk variables from childhood to adolescence was assessed by multivariate analysis (GEE). The model included birth weight (low vs control) and risk variables as applicable along with age, age ${ }^{2}$, race and gender and their interaction with birth weight (low vs control). A backward stepwise method was used to remove nonsignificant terms.

\section{Results}

Mean levels of cardiovascular risk variables during childhood (ages 4-11 years) and adolescence (ages 12-18 years) periods are shown in table 1 by birth weight groups. Of the risk variables adjusted for age, race, and gender, levels of HDL cholesterol were significantly lower and LDL cholesterol higher among low birth weight group vs control group during childhood. During adolescence, only glucose levels were significantly higher among low birth weight group vs control group.

Longitudinal rates of change in cardiovascular risk variables from childhood to adolescence, adjusted for race and gender, are presented in table 2 by birth weight groups. The rate of increase in BMI was significantly lower in low birth weight group compared with control group, while the rate of increase in subscapular skinfold remained similar between the groups. With respect to blood pressure, the rate of increase in systolic blood pressure was significantly higher in low birth weight group than control group. Of the measures of glucose homeostasis, rate of increase of glucose was marginally significant in low birth weight group vs control group. Low birth weight was associated with significantly higher rate of increase in LDL cholesterol; and no significant trends in HDL cholesterol and triglycerides.

Table I: Levels (mean \pm SD) of risk variables during childhood and adolescence by birth weight. The Bogalusa Heart Study

\begin{tabular}{lcccc}
\hline Variable & \multicolumn{2}{c}{ Childhood (4-I l years) } & Adolescence (I2-I8 years) \\
\cline { 2 - 5 } & Low Birth Weight & Control & Low Birth Weight & Control \\
\hline BMI $\left(\mathrm{kg} / \mathrm{m}^{2}\right)$ & $16.7 \pm 2.6$ & $17.5 \pm 2.9$ & $21.6 \pm 5.2$ & $22.7 \pm 5.0$ \\
Subsc. Skinfold $(\mathrm{mm})$ & $8.2 \pm 5.1$ & $8.3 \pm 6.4$ & $15.9 \pm 10.0$ & $16.0 \pm 10.7$ \\
Syst. BP $(\mathrm{mm} \mathrm{Hg})$ & $96.4 \pm 9.0$ & $98.6 \pm 8.1$ & $108.8 \pm 9.1$ & $105.2 \pm 8.7$ \\
Diast. BP $(\mathrm{mm} \mathrm{Hg})$ & $57.2 \pm 10.2$ & $58.7 \pm 7.9$ & $66.1 \pm 8.0$ & $66.4 \pm 7.4$ \\
Triglycerides $(\mathrm{mg} / \mathrm{dL})$ & $62.6 \pm 23.2$ & $52.8 \pm 20.3$ & $87.1 \pm 29.0$ & $83.2 \pm 35.3$ \\
HDL cholesterol $(\mathrm{mg} / \mathrm{dL})$ & $44.3 \pm 22.6^{\mathrm{a}}$ & $54.7 \pm 17.4$ & $99.9 \pm 12.8$ & $51.2 \pm 11.5$ \\
LDL cholesterol $(\mathrm{mg} / \mathrm{dL})$ & $76.0 \pm 35.4$ a & $68.6 \pm 37.6$ & $85.4 \pm 8.2^{\mathrm{b}}$ & $98.4 \pm 24.3$ \\
Glucose $(\mathrm{mg} / \mathrm{dL})$ & $79.7 \pm 8.1$ & $80.9 \pm 9.7$ & $14.8 \pm 7.5$ & $81.6 \pm 7.4$ \\
Insulin $(\mu \mathrm{u} / \mathrm{mL})$ & $8.5 \pm 5.7$ & $7.4 \pm 4.6$ & $3.0 \pm 2.4$ & $13.2 \pm 8.6$ \\
HOMA-IR & $1.7 \pm 1.2$ & $1.6 \pm 1.0$ & $2.7 \pm 2.0$
\end{tabular}

Difference between groups (adjusted for age, race, and gender), a: $p=0.05 ; b: p=0.02$

HOMA-IR: homeostasis model assessment index of insulin resistance 
Table 2: Rates of change in risk variables from childhood to adolescence by birth weight. The Bogalusa Heart Study

\begin{tabular}{lccc}
\hline \multicolumn{1}{c}{ Variable } & Low Birth Weight & Control & P-value \\
\hline BMI $\left(\mathrm{kg} / \mathrm{m}^{2} / \mathrm{y}\right)$ & $0.60 \dagger$ & 0.71 & 0.03 \\
Subsc. Skinfold $(\mathrm{mm} / \mathrm{y})$ & 0.91 & 1.12 & 0.27 \\
Syst. BP $(\mathrm{mmHg} / \mathrm{y})$ & 1.70 & 1.30 & 0.02 \\
Diast. BP $(\mathrm{mm} \mathrm{Hg} / \mathrm{y})$ & 1.21 & 1.02 & 0.26 \\
Triglycerides $(\mathrm{mg} / \mathrm{dL} / \mathrm{y})$ & 2.28 & 2.92 & 0.80 \\
HDL cholesterol $(\mathrm{mg} / \mathrm{dL} / \mathrm{y})$ & -0.53 & -0.91 & 0.24 \\
LDL cholesterol $(\mathrm{mg} / \mathrm{dL} / \mathrm{y})$ & 0.80 & 0.64 & 0.05 \\
Glucose $(\mathrm{mg} / \mathrm{dL} / \mathrm{y})$ & 0.50 & 0.11 & 0.07 \\
Insulin $(\mu \mathrm{u} / \mathrm{mL} / \mathrm{y})$ & 0.79 & 0.67 & 0.70 \\
HOMA-IR & 0.18 & 0.14 & 0.44 \\
\hline
\end{tabular}

tRegression slope with respect to age in years (y) adjusted for race and gender (generalized equation estimation method). HOMA-IR: homeostatis model assessment index of insulin resistance.

Table 3: Independent association of low birth weight with longitudinal trends of systolic blood pressure, triglycerides and glucose from childhood to adolescence

\begin{tabular}{|c|c|c|c|c|c|c|}
\hline \multirow[t]{2}{*}{ Independent Variables Retained } & \multicolumn{2}{|c|}{ Syst. BP } & \multicolumn{2}{|c|}{ Triglycerides } & \multicolumn{2}{|c|}{ Glucose } \\
\hline & $\beta^{\dagger}$ & $\mathrm{p}$-value & $\beta$ & $\mathrm{p}$-value & $\beta$ & P-value \\
\hline Birth Weight (low vs control) & 3.84 & 0.02 & 48.6 & 0.08 & 15.20 & 0.07 \\
\hline Gender (male vs female) & -- & -- & -- & -- & 4.31 & $<0.001$ \\
\hline Age & 0.39 & 0.40 & $|2.2|$ & 0.01 & 6.60 & $<0.001$ \\
\hline $\mathrm{Age}^{2}$ & 0.06 & 0.002 & -0.44 & 0.04 & -0.31 & $<0.001$ \\
\hline Insulin & 0.11 & 0.03 & 1.16 & $<0.001$ & 0.22 & 0.02 \\
\hline BMI & 0.34 & $<0.001$ & -- & -- & -- & -- \\
\hline Birth weight $\times$ age & 0.45 & 0.004 & $12.7 \mid$ & 0.03 & 0.10 & 0.07 \\
\hline Birth weight $\times$ age $^{2}$ & -- & -- & 0.55 & 0.02 & 2.65 & 0.10 \\
\hline
\end{tabular}

tGEE regression coefficient. The model included birth weight (low vs control) along with age, age ${ }^{2}$, race, and gender, and their interaction with birth weight; and risk variable as applicable.

In a multivariate analysis, low birth weight was retained as an independent predictor variable for adverse longitudinal trends in systolic blood pressure, triglycerides, and glucose (marginal) from childhood to adolescence, regardless of race or gender (table 3 ). Further, there was a significant interaction between low birth weight and age in this regard, denoting that these variables increased to a greater extent in the low birth weight group than in the control group as individuals became older. An analysis of this data set using the WHO criterion for low birth weight (<2500 g) showed that only 36 subjects were reclassified as having normal birth weight, and the results were essentially the same (data not shown).

\section{Discussion}

Information is sparse at a community level in the U.S. general population regarding the effects of low birth weight on the longitudinal trends in $\mathrm{C}-\mathrm{V}$ risk factor varia- bles measured serially and concurrently from childhood to adolescence. The present community-based study demonstrates the adverse effects of low birth weight on the longitudinal (developmental) trends in systolic blood pressure, triglycerides, and glucose during childhood and adolescence, regardless of race or gender. These observations are in accord with the emerging evidence supporting the concept of intrauterine imprinting and its pathophysiologic consequences enunciated by the fetal origin or thrifty phenotype hypothesis [3].

Many, but not all, previous studies in children and adolescents have found adverse associations between birth weight and levels of cardiovascular risk factor variables [16-27]. In this study, the magnitude of differences in mean levels of cardiovascular risk factor variables between low birth weight and control groups during childhood and adolescence periods were small and nonsignificant 
for most of the study variables, except for the adverse levels HDL cholesterol and LDL cholesterol in childhood and glucose in adolescence among the low birth weight group. However, in a multivariate analysis of the serial data, the independent adverse effects of low birth weight on the longitudinal trends of systolic blood pressure, triglycerides, and glucose were discernable in the study cohort. Of note, the observed adverse trends associated with low birth weight vs control group were influenced by age in that the differences became greater in magnitude as the children got older. Earlier studies have reported that the inverse associations between birth weight and levels of cardiovascular risk factor variables became stronger with increasing age $[26,38]$. Whether the potentiating effect of increasing age on low birth weight - risk variable relationship reflects the interaction between fetal programming related to intrauterine malnutrition and the increasing burden with age of unhealthy life-style behaviors including overnutrition and sedentary life style is not clear. In this context, it should be noted that although the rate of yearly increase in BMI, which also includes muscle mass, was significantly lower in low birth weight group, the rate of increase in subscapular skinfold, a measure of truncal fat, remained similar to that of control group. This suggests a gaining of truncal fat, in relative term, over muscle mass in the low birth weight group.

Although observational studies like the present one can not establish causality, several putative mechanisms link low birth weight to adverse trends in risk factor variables. It has been suggested that insulin resistance may be one mechanism by which intrauterine events may program disease risk [39]. Undernutrition in utero is known to cause permanent impairment in growth, structure and function of muscle $[39,40]$, fat $[41,42]$, endocrine pancreas [2,43], liver [30], renal nephrons $[44,45]$ and vasculature [46] due to biologic programming, resulting in insulin resistance/glucose intolerance, hypertension, and dyslipidemia. Further, it has been suggested that intrauterine programming of the hypothalamic-pituitary-adrenal axis may be a functional mechanism underlying the link between low birth weight and above disorders [47], known as components of insulin resistance or metabolic syndrome [48].

This study has certain limitations. The lack of information on the duration of gestation precluded us from adjusting the birth weight for gestational age, a potential confounder. However, earlier studies have found that adverse effects of low birth weight on cardiovascular risk factor variables were independent of gestation period $[10,17,49]$. Further, it has been pointed out that inclusion of preterm births could actually underestimate these associations [28]. This study also lacks measurements of glucose tolerance and insulin action and secretion used in etiologic studies. Instead, we used the glucose homeostasis measures that are relatively easily measured and applicable at a population level.

\section{Conclusions}

Low birth is characterized by adverse developmental trends in metabolic and hemodynamic variables during childhood and adolescence, especially as the children get older. These observations in conjunction with earlier findings support the view that low birth weight, albeit a crude marker of prenatal growth and physiological environment, is a potential early risk factor for the emergence of metabolic and hemodynamic disorders and related diseases $[1,50]$.

\section{Abbreviations}

BMI, body mass index; LDL, low-density lipoprotein; HDL, high-density lipoprotein

\section{Competing interests}

The author(s) declare that they have no competing interests.

\section{Authors' contributions}

MGF participated in study design, data analysis and manuscript preparation. SRS and GSB contributed to study concept and design, data collection, acquisition of funding and manuscript preparation. JX was involved in measurements of laboratory variables. All authors read and approved the final manuscript.

\section{Acknowledgements}

Supported by NIH grants AG-16592 from the National Institute on Aging; HL-38844 from the National Heart, Blood and Lung Institute; and HD-

043820 from the National Institute of child Health and Human

Development.

The Bogalusa Heart Study is a joint effort of many investigators and staff members whose contribution is gratefully acknowledged. We especially thank the Bogalusa, LA school system and the participants and their parents.

\section{References}

I. Barker DJ: Mothers, Babies and Health in Later Life. 2nd edition. Edinburgh, United Kingdom: Churchill Livingstone; 1998.

2. Hales CN, Barker DJ: Type 2 (non-insulin-dependent) diabetes mellitus: the thrifty phenotype hypothesis. Diabetologia 1992, 35:595-601.

3. McCance DR, Pettitt DJ, Hanson RL, Jacobsson LTH, Knowler WC, Bennet PH: Birth weight and non-insulin dependent diabetes: thrifty genotype, thrifty phenotype, or surviving small baby genotype? BMJ 1994, 308:942-945.

4. Waterland RA, Garza C: Potential mechanisms of metabolic imprinting that lead to chronic disease. Am J Clin Nutr 1999, 69:179-197.

5. Wilkin TJ, Metcalf BS, Murphy MJ, Kirkby J, Jeffery AN, Voss LD: The relative contributions of birth weight, weight change, and current weight to insulin resistance in contemporary 5-year olds. The Early Bird Study. Diabetes 2002, 51:3468-3472.

6. Progress Towards Health for All. Statistics of Member States. Geneva, World Health Organization; 1994:26-35. 
7. Martin JA, Hamilton BE, Sutton PD, Ventura SJ, Menacker F, Munson ML: Births: final data for 2002. Natl Vital Stat Rep 2003, 52: 1043.

8. Barker DJP, Hales CN, Fall CH, Osmond C, Phipps K, Clark PMS Type 2 (non-insulin-dependent) diabetes mellitus, hypertension and hyperlipidemia (Syndrome $X$ ): relation to reduced fetal growth. Diabetologia 1993, 36:62-67

9. Fall CHD, Stein CE, Kumaran K, Cox V, Osmond C, Barker DJP, Hales CN: Size at birth, maternal weight, and non-insulin dependent diabetes in South India. Diabet Med 1998, I 5:220-227.

10. Rich-Edwards JW, Colditz GA, Stampfer MJ, Willet WC, Gillman MW, Hennekens $\mathrm{CH}$, Speizer FE, Manson JE: Birth weight and the risk of type 2 diabetes mellitus in adult women. Ann Intern Med 1999, I 30:278-284.

II. Valdez R, Athens MA, Thompson GH, Bradshaw BS, Stern MP: Birth weight and adult health outcomes in a bi-ethnic population in the USA. Diabetologia 1996, 37:624-631.

12. Barker DJP, Osmond C, Winter PD, Margetts B, Simmonds S]: Weight in infancy and death from ischemic heart disease. Lancet 1989, 2:577-580.

13. Leon DA, Lithell HO, Vageno D, Koupilova I, Mohsen R, Berglund L: Reduced fetal growth rate and increased risk of death from ischaemic heart disease: cohort study of 15,000 Swedish men and women born I9I5-I929. BMJ 1998, 317:241-244.

14. Falkner B, Hulmann S, Kushner $\mathrm{H}$ : Birth weight versus childhood growth determinants of adult blood pressure. Hypertension I998, 3 I (part I): |45-I50.

15. Huxley R, Neil A, Collins R: Unravelling the fetal origins' hypothesis: is there really an inverse association between birth weight and subsequent blood pressure? Lancet 2002, 360:659-665.

16. Williams S, St George IM, Silva PA: Intrauterine growth retardation and blood pressure at age seven and eighteen. J Clin Epidemiol 1992, 45: 1257-1263.

17. Uiterwaal CSP, Anthony S, Lanner LJ, Witterman JCM, Trouwborst AMW, Hofman A, Grobbee DE: Birth weight, growth, and blood pressure. An annual follow-up study of children aged 4 through 21 years. Hypertension 1997, 30(part I):267-27I.

18. Forrester TE, Willes RJ, Bennett FI, Simeon D, Osmond C, Allen M, Chung AP, Scott $P$ : Fetal growth and cardiovascular risk factors in Jamaican school children. BMJ 1996, 3 I 2:156-160.

19. Falkner B, Hulman S, Kushner H: Effect of birth weight on blood pressure and body size in early adolescence. Hypertension 2004, 43:203-207.

20. Whincup PH, Cook DG, Shaper AG: Early influence on blood pressure: a study of children aged 5-7 years. BMJ 1989 , 299:587-59l.

21. Donker GA, Labarthe DR, Harris RB, Selwyn BJ, Wattigney W, Berenson GS: Low birth weight and blood pressure at age 7-I I years in a biracial sample. Am J Epidemiol I997, I45:387-397.

22. Donker GA, Labarthe DR, Harris RB, Selwyn BJ, Srinivasan SR, Wattigney W, Berenson GS: Low birth weight and serum lipid concentrations at age $7-1 \mathrm{I}$ years in a biracial sample. Am Epidemiol 1997, 45:398-407.

23. Mzayek F, Sherwin R, Fonseca V, Valdez R, Srinivasan SR, Cruickshank JK, Berenson GS: Differential association of birth weight with cardiovascular risk variables in African-Americans and Whites: The Bogalusa Heart Study. Ann Epidemiol 2004, | 4:258-264.

24. Bardekar A, Yajnik CS, Chittaranjan S, Fall CHD, Bapat S, Pandit AN, Deshpande V, Bhave S, Kellingray SD, Joglekar C: Insulin resistance syndrome in 8-year old Indian children: small at birth, big at 8 years, or both? Diabetes 1999, 48:2422-2429.

25. Dabelea D, Pettitt DJ, Hanson RL, Imperatore G, Bennett PH, Knowler WC: Birth weight, type 2 diabetes, and insulin resistance in Pima Indian children and young adults. Diabetes Care 1999, 22:944-950.

26. Li C, Johnson MS, Goran MI: Effects of low birth weight on insulin resistance syndrome in Caucasian and African-American children. Diabetes Care 200I, 24:2035-2042.

27. Murtaugh MA, Jacobs DR Jr, Moran A, Steinberger J, Sinaiko AR: Relation of birth weight to fasting insulin, insulin resistance, and body size in adolescence. Diabetes Care 2003, 26:187-192.

28. The Bogalusa Heart Study 20th Anniversary Symposium. Am J Med Sci 1995:SI-SI38.
29. Jensen CB, Storgaard H, Dela F, Holst J], Madsbad S, Vaag AA: Early differential defects of insulin secretion and action in 19-year old Caucasian men who had low birth weight. Diabetes 2002, 5 I: | 27| - | 280.

30. Barker DJ, Martyn CN, Osmond C, Wield GA: Abnormal liver growth in utero and death from coronary heart disease. $B M$ J |995, 3 | 0:703-704.

31. Frerichs RR, Srinivasan SR, Webber LS, Rieth MC, Berenson GS: Serum lipids and lipoproteins at birth in a biracial population: the Bogalusa Heart Study. Pediatr Res 1978, I 2:858-863.

32. Alexander GR, Kogan MD, Himes JH: I994-I996 U.S. singleton birth weight percentiles for gestational age by race, Hispanic origin, and gender. Matern Child Health J 1999, 3:225-23 I.

33. Berenson GS, McMahan CA, Voors AW, Webber LS, Srinivasan SR, Frank GC, Foster TA, Bland CV: Cardiovascular risk factors in children. The early natural history of atherosclerosis and essential hypertension. Oxford: Oxford University Press; 1980.

34. Elkasabany AM, Urbina EM, Daniels SR, Berenson GS: Prediction of adult hypertension by $\mathrm{K} 4$ and $\mathrm{K5}$ diastolic blood pressure in children: The Bogalusa Heart Study. J Pediatr 1998, 132:687-692.

35. Srinivasan SR, Berenson GS: Serum lipoproteins in children and methods for study. In In: CRC Handbook of Electrophonesis. Lipoprotein methodology human studies Volume III. Edited by: Lewis LA. CRC Press: Boca Raton, FL; 1983:185-203.

36. Mathews DR, Hosker JP, Rudenski AS, Naylor BA, Treacher DF Turner RC: Homeostasis model assessment: insulin resistance and $\beta$-cell function from fasting plasma glucose and insulin concentrations in man. Diabetologia 1985, 28:4I2-|49.

37. Diggle PJ, Liang KY, Zeger SL: Analysis of Longitudinal Data. New York, NY Oxford University Press; 1994.

38. Law CM, de Swiet M, Osmond C, Fayers PM, Barker DJ, Cruddas AM, Fall $\mathrm{CH}$ : Initiations of hypertension in utero and its amplifications throughout life. $B M]$ 1993, 306:24-27.

39. Phillips DIW: Insulin resistance as a programmed response to fetal malnutrition. Diabetologia 1996, 39: III9-1122

40. Taylor DJ, Thompson CH, Kemp GJ, Barnes PRJ, Sanderson A, Radda GK, Phillips DI: A relationship between impaired fetal growth and reduced muscle glycolysis reveled by $31 \mathrm{P}$ magnetic resonance spectroscopy. Diabetologia 1995, 38: I205-I2I 2 .

41. Lapillone A, Braillon P, Chatelain PA, Delmas PD, Salle BD: Body composition in appropriate and small for gestational age infants. Acta Paedriatr 1997, 86:196-200.

42. Jaquet $D$, Gaboriau $A$, Czernichow $P$, Levy-Marchal $C$ : Insulin resistance early in adulthood in subject born with intrauterine growth retardation. J Clin Endocrinol Metab 2000, 85: |40 | - |406.

43. Dahri S, Reusens B, Remacle C, Hoet J): Nutritional influences on pancreatic development and potential links with non-insulindependent diabetes. Prac Nutr Soc 1995, 54:345-356.

44. MacKenzie HS, Brenner BM: Fewer nephrons at birth: a missing link in the etiology of essential hypertension? Am J Kidney Dis 1995, 26:91-98.

45. Hinchliffe SA, Lynch MRJ, Sargent PH, Howard CV, Velzen DV: The effect of intrauterine growth retardation on the development of renal nephrons. Br J Obstet Gynecol 1992, 99:296-30I.

46. Leeson CP, Whincup PH, Cook DG, Donald AE, Papacosta O, Lucas $A$, Deanfield JE: Flow-mediated dilation in 9- to II-year-old children: the influence of intrauterine and childhood factors. Circulation 1997, 96:2233-2238.

47. Phillips DI, Barker DJ, Fall CH, Seckl JR, Whorwood CB, Wood PJ, Walker BR. Elevated plasma cortisol concentrations: a link between low birth weight and the insulin resistance syndrome. J Clin Endocrinol Metab 1998, 83:757-760.

48. Reaven GM: Role of insulin resistance in human disease. Diabetes 1988, 37:1595-1607.

49. Forsen T, Eriksson J, Tuomilehto J, Reunanen A, Osmond C, Barker $D$ : The fetal growth and childhood growth of persons who develop type 2 diabetes. Ann Intern Med 2000, I33:I76-I82.

50. Eriksson JG: Growth and coronary heart disease in adult life. Cardiovasc Res Rev 2002, 23:557-0560.

\section{Pre-publication history}

The pre-publication history for this paper can be accessed here: 
http://www.biomedcentral.com/1471-2431/4/22/prepub

Publish with Bio Med Central and every scientist can read your work free of charge

"BioMed Central will be the most significant development for disseminating the results of biomedical research in our lifetime. " Sir Paul Nurse, Cancer Research UK

Your research papers will be:

- available free of charge to the entire biomedical community

- peer reviewed and published immediately upon acceptance

- cited in PubMed and archived on PubMed Central

- yours - you keep the copyright 